ISTIGHNA, Vol. 1, No 1, Januari 2018 P-ISSN 1979-2824

Homepage: http://e-journal.stit-islamic-village.ac.id/index.php/istighna

Deden Saeful Ridhwan MZ

Esensi Pendidikan Islam Dalam Perspektif KH. Abdurrahman Wahid

\title{
ESENSI PENDIDIKAN ISLAM DALAM PERSPEKTIF KH. ABDURRAHMAN WAHID
}

\author{
Deden Saeful Ridhwan MZ \\ (dedensaeful_ridhwan@yahoo.com)
}

Dosen Sekolah Tinggi Ilmu Tarbiyah (STIT) Islamic Village Tangerang

\begin{abstract}
Abstrak: Pembaharuan pendidikan Islam dan modernisasi pendidikan Islam, dalam bahasa Arab taj'did al-tarbiyah al-Islamiah dan al-hadasah, dalam liputan istilah pertama, tentu saja ajaran-ajaran formal Islam harus diutamakan, dan kaum muslimin harus dididik mengenai ajaran-ajaran agama mereka. Yang diubah adalah cara penyampaiannya kepada peserta didik, sehingga mereka akan mampu memahami dan mempertahankan "kebenaran". Bahwa hal ini memiliki validitas sendiri, dapat dilihat pada kesungguhan anak-anak muda muslimin terpelajar, untuk menerapkan apa yang mereka anggap sebagai "ajaran-ajaran yang benar" tentang Islam,
\end{abstract}

Kata Kunci: Gagasan, Metodologi, Strategi Pendidikan Islam

\section{A. Pendahuluan}

Pendidikan Islam tidak hanya disampaikan dalam ajaran-ajaran formal Islam di sekolah-sekolah agama/madrasah belaka, melainkan juga melalui sekolah-sekolah non-agama yang berserak diseluruh penjuru dunia. Demikian juga, "semangat menjalankan ajaran Islam", datangnya lebih banyak dari komunikasi di luar sekolah, antara berbagai komponen masyarakat Islam. Hal lain yang harus diterima sebagai kenyataan hidup kaum muslimin di mana-mana, adalah respon umat Islam terhadap "tantangan modernisasi",204, seperti pengentasan kemiskinan, pelestarian lingkungan hidup dan sebagainya, adalah respon yang tak kalah bermanfaatnya bagi pendidikan Islam, yang perlu kita renungkan secara mendalam. ${ }^{205}$

Pendidikan Islam memiliki begitu banyak model pengajaran baik yang berupa pendidikan sekolah, maupun "pendidikan non-formal” seperti pengajian,

${ }^{204}$ Endang Turmudi (ed), Nahdlatul Ulama Ideoligy Politics and the Formation of Khaira Ummah (Jakarta: The Central Board of The Ma'arif Education Institution of NU, 2004), h. 123

${ }^{205}$ Aceng Abdul Aziz (ed), Performa Masa Depan Ma'arif NU (Jakarta: PP Ma'arif NU, 2009), h. 10, 
ISTIGHNA, Vol. 1, No 1, Januari 2018 P-ISSN 1979-2824

Homepage: http://e-journal.stit-islamic-village.ac.id/index.php/istighna

Deden Saeful Ridhwan MZ

Esensi Pendidikan Islam Dalam Perspektif KH. Abdurrahman Wahid

arisan dan sebagainya. ${ }^{206}$ Tak terhindarkan lagi, keragaman jenis dan corak pendidikan Islam terjadi seperti kita lihat di tanah air kita dewasa ini. Ketidakmampuan memahami kenyataan ini, yaitu hanya melihat lembaga pendidikan formal seperti sekolah dan madrasah di tanah air sebagai sebuah institusi pendidikan Islam, hanyalah akan mempersempit pandangan kita tentang pendidikan Islam itu sendiri. Ini berarti, kita hanya mementingkan satu sisi belaka dari pendidikan Islam, dan melupakan sisi non-formal dari pendidikan Islam itu sendiri. $^{207}$ Tentu saja menjadi berat tugas para perencana pendidikan Islam, kenyataan ini menunjukkan disinilah terletak lokasi perjuangan pendidikan Islam. $^{208}$

Dalam tulisan ini akan mencoba menganalisa pemikiran $\mathrm{KH}$. Abdurrahman Wahid yang memang dikategorikan sebagai "Guru Bangsa",209 yang memiliki pemikiran yang futuristik khususnya dalam bidang pendidikan Islam.

\section{B. Konsepsi Pendidikan di Indonesia}

Dalam pandangan K.H. Abdurrahman Wahid tentang pendidikan di Indonesia, menurutnya konsepsi pendidikan di Indonesia berjalan di atas konsepsi yang salah. Konsepsi yang salah tersebut tidak mampu membebaskan manusia dari kebodohan dan keterbelakangan. Letak kesalahannya adalah karena pendidikan kita ini menekankan pada ijazah formal, bukan pada substansinya untuk memanusiakan manusia. Dengan sistem pendidikan yang menekankan pada ijazah formal seperti sekarang, jabatan seseorang di masyarakat ditentukan oleh ijazah yang dimilikinya. Bukan ditentukan oleh kompetensi dan kualitas riilnya. Intinya, jika memiliki ijazah formal, orang tersebut dapat meraih jabatan-jabatan penting di pemerintahan dan kedudukan bergengsi di tengah-tengah masyarakat yang biasanya dimasuki oleh seseorang dengan ukuran ijazah tertentu. Akibat dari

${ }^{206}$ Chairul Fuad Yusuf (ed), Karakteristik Majlis Taklim (Jakarta: GP Press, 2007), h. 2. Lihat juga, A. Munir Sonhadji, Pesantren as a Model of Non Formal Islamic Education (International Journal of Pesantren Studies, Volume 1, Number 1, 2007), h. 1.

207 Mulyadhi Kartanegara, Reaktualisasi Tradisi Ilmiyah Islam (Jakarta: Baitul Ihsan, 2006), h. 27.

${ }^{208}$ Mahmud Arif, Pendidikan Islam Transformatif, (Jogjakarta: LKiS, 2008), h. 171. Bandingkan dengan Mujamil Qomar, Epistemologi Pendidikan Islam dari Metode Rasional hingga Metode Kritik (Jakarta: Erlangga, tt), h. i.

209 Bahtiar Effendy, Gus Dur dan Pupusnya Dwi Tunggal. Retaknya Hubungan NU, Presiden, dan Negara (Jakarta: Ushul Press, 2005), h. viii. 
ISTIGHNA, Vol. 1, No 1, Januari 2018 P-ISSN 1979-2824

Homepage: http://e-journal.stit-islamic-village.ac.id/index.php/istighna

Deden Saeful Ridhwan MZ

Esensi Pendidikan Islam Dalam Perspektif KH. Abdurrahman Wahid

konsepsi pendidikan tersebut, di negara kita banyak orang yang memburu ijazah formal hanya karena ingin gengsi-gengsian dan mendapat jabatan resmi semata. Orang belajar ke sekolah atau ke kampus bukan untuk mencari ilmu, tetapi untuk mencari ijazah demi syarat formal untuk mendapat kedudukan. Pendidikan yang berorientasi pada formalitas ijazah hanyalah pendidikan tipu-tipuan. ${ }^{210}$

Ketika menjadi dosen, sempat bingung menghadapi absen. Ketika selesai perkuliahan, mahasiswa Jurusan Sejarah Fakultas Adab IAIN Jakarta menyodorkan absen, Gus Dur terperangah. “Apa ini?” Gus Dur bertanya. Mahasiswa tersebut menjawab, "Ini daftar hadir dosen". Gus Dur pun menolak untuk menandatanganinya. Hal yang ditunjukkan oleh Gus Dur ini merupakan bentuk keseriusan dan konsistensi Gus Dur dengan konsepsi pendidikan yang diinginkannya, yakni pendidikan yang berfokus pada pembentukan akhlak peserta didik, bukan pada perburuan ijazah formal atau pencarian gelar belaka. ${ }^{211}$

Gus Dur mengatakan salah satu ajaran yang dengan sempurna menampilkan universalisme Islam adalah lima buah jaminan dasar yang diberikan agama samawi terakhir ini kepada warga masyarakat, baik secara perorangan maupun sebagai kelompok. Lima jaminan dasar tersebut adalah: Agama, jiwa, akal, harta dan keturunan. Untuk menyelamatkan akal Islam mewajibkan belajar disepanjang hayatnya, demi kelancaran proses tersebut dibutuhkan lembaga pendidikan sekaligus melarang hal-hal yang merusak akal seperti minuman keras. Upaya untuk mewujudkan pendidikan sebagai sarana untuk melindungi akal menjadi wajib dilakukan, karena ini merupakan salah satu bentuk pribumisasi Islam. Dengan cara yang demokratis, semua bisa ikut serta dan berpartisipasi dalam proses pembelajaran serta menghargai pendapat orang lain dan melihat perbedaan sebagai kemajemukan. $^{212}$

Hal ini sesuai dengan jawaban Gus Dur dalam wawancaranya mengenai pendidikan yang diberikan kepada anak-anaknya:

${ }^{210}$ Sulton Fatoni, The Wisdom of Gus Dur, (Depok: Imania, 2014), Cet.1, h. 288-289

${ }^{211}$ E. Kosasih, Hak Gus Dur untuk Nyleneh, (Bandung: Pustaka Hidayah, 2000). Cet. ke-1. h. 258

${ }^{212}$ Lihat Nandirotul Umah, Pendidikan Islam di Indonesia Perspektif K.H. Abdurrahman Wahid, Program Studi Pendidikan Agama Islam, STAIN Salatiga, 2013. h. 21 
ISTIGHNA, Vol. 1, No 1, Januari 2018 P-ISSN 1979-2824

Homepage: http://e-journal.stit-islamic-village.ac.id/index.php/istighna

Deden Saeful Ridhwan MZ

Esensi Pendidikan Islam Dalam Perspektif KH. Abdurrahman Wahid

"Saya menanamkan tanggung jawab. Jadi terserah mereka mau jadi apa. Dari satu segi, anak saya kan perempuan semua. Saya cukup realistis. Kalau saya tanamkan supaya mereka bercita-cita, pertama, kan itu memaksakan kehendak kepada mereka. Kedua, toh mereka kawin dan nanti harus menyesuaikan diri dengan suami, Jadi sudah saya tekankan rasa tanggung jawab itu saja. Saya ingin memperingatkan kepada orang tua yang ingin anaknya berprestasi. Menurut saya, kita tidak boleh mendera mereka. Biar dia muncul dari kebutuhan mereka sendiri. Karena itu saya nanti saja kalau mengajarkan disiplin, tapi bukan supaya mereka mengejar angka-angka di kelas, misalnya. Umumnya, orang tua kalau anaknya tidak masuk rangking sepuluh, lalu kecewa. Saya nggak ada itu, karena saya dulu pernah nggak naik kelas, Jadi bagi saya itu bukan apaapa. Dan saya juga biasa-biasa saja, bukan orang yang punya prestasi hebat."

Dalam wawancara tersebut, Gus Dur menjadi contoh sosok pendidik yang berani dalam menerapkan kebebasan bagi kemajuan pendidikan anak-anaknya. Gus Dur menerapkan kebebasan dalam mendidik anak-anaknya, Gus Dur menghargai hak dan kewajiban setiap anaknya. Memberikan ruang sebebasbebasnya dalam mengekspresikan pemikirannya masing-masing.

\section{Gagasan Pendidikan Islam}

Gagasan K.H. Abdurrahman Wahid tentang pendidikan Islam secara jelas terlihat pada gagasannya tentang pembaharuan pesantren. Menurutnya, semua aspek pendidikan Islam mulai dari visi, misi, tujuan, kurikulum, manajemen dan kepemimpinannya harus diperbaiki dan disesuaikan dengan perkembangan zaman era globalisasi. Meski demikian, menurut Gus Dur pendidikan Islam khususnya di pesantren juga harus mempertahankan identitas dirinya sebagai penjaga tradisi keilmuan klasik, dalam arti tidak larut sepenuhnya dengan modernisasi, tapi mengambil sesuatu yang dipandang manfaat positif untuk perkembangan disamping itu pendidikan Islam harus lepas dari dikotomi pengetahuan. Hal ini 
ISTIGHNA, Vol. 1, No 1, Januari 2018 P-ISSN 1979-2824

Homepage: http://e-journal.stit-islamic-village.ac.id/index.php/istighna

Deden Saeful Ridhwan MZ

Esensi Pendidikan Islam Dalam Perspektif KH. Abdurrahman Wahid

dimaksudkan supaya peserta didik memiliki ilmu agama yang kuat sekaligus juga memiliki ilmu yang kuat secara seimbang. ${ }^{213}$

Dalam sebuah dialog tentang pendidikan Islam, berlangsung di Beirut (Lebanon) tanggal 13-14 Desember 2002 yang diselenggarakan oleh Konrad Adenauer Stiftung, ternyata disepakati adanya berbagai corak pendidikan agama, hal ini juga berlaku untuk pendidikan Islam. Walaupun ada beberapa orang yang terus terang mengakui, maupun yang menganggap pendidikan Islam yang benar haruslah mengajarkan "ajaran formal” tentang Islam. Termasuk dalam barisan ini adalah dekan-dekan Fakultas Syari'ah dan Perundang-undangan dari Universitas al-Azhar Kairo. Diskusi tentang mewujudkan "pendidikan Islam yang benar" memang terjadi, tapi tidak ada seorang peserta-pun yang menafikan dan mengingkari peranan berbagai corak pendidikan Islam yang telah ada. Gus Dur sendiri membawakan makalah tentang pondok pesantren sebagai bagian dari pendidikan Islam. $^{214}$

Dalam makalah tersebut, Gus Dur melihat pondok pesantren dari berbagai sudut. Pondok pesantren sebagai (lembaga kultural) yang menggunakan simbolsimbol budaya jawa; sebagai "agen pembaharuan" yang memperkenalkan gagasan pembangunan pedesaan (rural development), sebagai pusat kegiatan belajar masyarakat (centre of community learning), dan juga pondok pesantren sebagai lembaga pendidikan Islam yang bersandar pada silabi, yang dibawakan oleh Imam al-Suyuti lebih dari 500 tahun yang lalu, dalam Itman al-dirayah. Silabi inilah yang menjadi dasar acuan pondok pesantren tradisional selama ini, dengan pengembangan "kajian Islam" yang terbagi dalam 14 macam disiplin ilmu yang kita kenal sekarang ini, dari nahwu/ tata bahasa arab klasik hingga tafsir al-Qur'an dan teks hadis Nabi, semuanya dipelajari dalam lingkungan pondok pesantren sebagai sebuah lembaga pendidikan Islam. Melalui pondok pesantren juga nilai ke-Islam-an ditularkan dari generasi ke generasi. ${ }^{215}$

\footnotetext{
${ }^{213}$ Lihat Abdul Manab, Pendidikan Islam dalam Membangun Budaya Kosmopolitan Perspektif K.H. Abdurrahman Wahid, (Surabaya: IAIN Sunan Ampel_skripsi, 2012), h. 21

${ }^{214}$ KH. Abdurrahman Wahid, Pendidikan Islam Harus Beragam, Yogyakarta: Kedaulatan Rakyat, 2002. (sumber: Kedaulatan Rakyat, Jumat 21/12/2002)

215 Ibid. Lihat juga Amin Haedari (ed), Khazanah Intelektual Pesantren II (Jakarta: Kementerian Agama RI, 2010), h. xiii.
} 
ISTIGHNA, Vol. 1, No 1, Januari 2018 P-ISSN 1979-2824

Homepage: http://e-journal.stit-islamic-village.ac.id/index.php/istighna

Deden Saeful Ridhwan MZ

Esensi Pendidikan Islam Dalam Perspektif KH. Abdurrahman Wahid

Sudah tentu, cara penularan seperti itu merupakan titik sambung pengetahuan tentang Islam secara rinci, dari generasi ke generasi. Di satu sisi, ajaran-ajaran formal Islam dipertahankan sebagai sebuah "keharusan" yang diterima kaum muslimin diberbagai penjuru dunia. Tetapi, disini juga terdapat "benih-benih perubahan", yang membedakan antara kaum muslimin di sebuah kawasan dengan kaum muslimin lainnya dari kawasan yang lain pula. Tentang perbedaan antara kaum muslimin di suatu kawasan ini, Gus Dur pernah mengajukan sebuah makalah kepada Universitas PBB di Tokyo pada tahun 1980an. Tentang perlu adanya "study kawasan" tentang Islam di lingkungan Afrika Hitam, budaya Afrika Utara dan negeri-negeri Arab, budaya Turki-Persia-Afghan, budaya Islam di Asia Selatan, budaya Islam di Asia Tenggara dan budaya minoritas muslim di kawasan-kawasan industri maju. Sudah tentu, kajian kawasan (area study's) ini diteliti bersamaan dengan kajian Islam klasik (classiccal Islamic study's). ${ }^{216}$

Gus Dur memberikan tawaran terhadap pendidikan Islam dengan cara tajdid tarbiyah al-Islamiyah (pembaharuan pendidikan Islam) yaitu dengan memberikan pemahaman yang benar kepada peserta didik, sehingga mereka mampu memahami dan mempertahankan keyakinan mereka dan menghargai keyakinan orang lain tanpa harus melakukan suatu tindak anarkisme dalam rangka menghilangkan suatu perbedaan tersebut. ${ }^{217}$

Pendidikan Islam tidak hanya disampaikan dalam ajaran-ajaran formal Islam di sekolah-sekolah agama/madrasah belaka, melainkan juga melalui sekolah-sekolah non-agama yang berserak diseluruh penjuru dunia. Demikian juga, "semangat menjalankan ajaran Islam", datangnya lebih banyak dari komunikasi di luar sekolah, antara berbagai komponen masyarakat Islam. Hal lain yang harus diterima sebagai kenyataan hidup kaum muslimin di mana-mana, adalah respon umat Islam terhadap "tantangan modernisasi”, seperti pengentasan kemiskinan, pelestarian lingkungan hidup dan sebagainya, adalah respon yang tak

${ }^{216}$ Ibid.

${ }^{217}$ Lihat Abdul Manab, Pendidikan Islam dalam Membangun Budaya Kosmopolitan Perspektif K.H. Abdurrahman Wahid,, Op.cit. h. 78 
ISTIGHNA, Vol. 1, No 1, Januari 2018 P-ISSN 1979-2824

Homepage: http://e-journal.stit-islamic-village.ac.id/index.php/istighna

Deden Saeful Ridhwan MZ

Esensi Pendidikan Islam Dalam Perspektif KH. Abdurrahman Wahid

kalah bermanfaatnya bagi pendidikan Islam, yang perlu kita renungkan secara mendalam.

Pendidikan Islam, tentu saja harus sanggup "meluruskan" responsi terhadap tantangan modernisasi itu, namun kesadaran kepada hal itu justru belum ada dalam pendidikan Islam di mana-mana. Hal inilah yang merisaukan hati para pengamat seperti Gus Dur, karena ujungnya adalah diperlukan jawaban yang benar atas pernyataan berikut: Bagaimanakah caranya membuat kesadaran struktural sebagai bagian natural dari perkembangan pendidikan Islam? Dengan ungkapan lain, kita harus menyimak perkembangan pendidikan Islam di berbagai tempat, dan membuat peta yang jelas tentang konfigurasi pendidikan Islam itu sendiri. Ini merupakan pekerjaan rumah, yang mau tak mau harus ditangani dengan baik.

Jelas dari uraian di atas, pendidikan Islam memiliki begitu banyak model pengajaran baik yang berupa pendidikan sekolah, maupun "pendidikan nonformal" seperti pengajian, arisan dan sebagainya. Tak terhindarkan lagi, keragaman jenis dan corak pendidikan Islam terjadi seperti kita lihat di tanah air kita dewasa ini. Ketidakmampuan memahami kenyataan ini, yaitu hanya melihat lembaga pendidikan formal seperti sekolah dan madrasah di tanah air sebagai sebuah institusi pendidikan Islam, hanyalah akan mempersempit pandangan kita tentang pendidikan Islam itu sendiri. Ini berarti, kita hanya mementingkan satu sisi belaka dari pendidikan Islam, dan melupakan sisi non-formal dari pendidikan Islam itu sendiri. Tentu saja menjadi berat tugas para perencana pendidikan Islam, kenyataan ini menunjukkan di sinilah terletak lokasi perjuangan pendidikan Islam. $^{218}$

Karenanya, peta "keberagaman" pendidikan Islam seperti dimaksudkan di atas, haruslah bersifat lengkap dan tidak mengabaikan kenyataan yang ada. Lagilagi kita berhadapan dengan kenyataan sejarah, yang mempunyai hukumhukumnya sendiri. Perkembangan keadaan, yang tidak memperhitungkan hal ini, mungkin hanya bersifat menina-bobokan kita belaka, dari tugas sebenarnya yang harus kita pikul dan laksanakan. Sikap untuk mengabaikan keberagaman ini,

${ }^{218}$ KH. Abdurrahman Wahid, Pendidikan Islam Harus Beragam, Loc.cit. 
ISTIGHNA, Vol. 1, No 1, Januari 2018 P-ISSN 1979-2824

Homepage: http://e-journal.stit-islamic-village.ac.id/index.php/istighna

Deden Saeful Ridhwan MZ

Esensi Pendidikan Islam Dalam Perspektif KH. Abdurrahman Wahid

adalah sama dengan sikap burung onta yang menyembunyikan kepalanya di bawah timbunan pasir tanpa menyadari badannya masih tampak. Jika kita masih bersikap seperti itu, akibatnya akan menjadi sangat besar bagi perkembangan Islam di masa yang akan datang. Karenanya jalan terbaik adalah membiarkan keaneka-ragaman sangat tinggi dalam pendidikan Islam dan membiarkan perkembangan yang akan menentukan. ${ }^{219}$

Gus Dur menginginkan, agar di samping mencetak ahli ilmu agama Islam, pendidikan Islam juga mampu mencetak orang yang memiliki keahlian dalam ilmu pengetahuan dan teknologi yang pada akhirnya berguna untuk perkembangan masyarakat itu sendiri. Dengan itu Gus Dur menginginkan ada perubahan pada kurikulum dalam dunia pendidikan Islam menurutnya selain harus kontekstual dengan kebutuhan zaman juga harus mampu merangsang daya intelektual kritis anak didik. Dalam menghantarkan peserta didik menjadi manusia yang utuh, mandiri dan bebas dari belenggu penindasan. Atau dengan kata lain adalah pendidikan yang memerdekakan manusia. ${ }^{220}$

\section{D.. Pondok Pesantren Menurut "Gus Dur"}

Dalam prolog atau pengantar sebuah buku yang berjudul "Pesantren Masa Depan: Wacana pemberdayaan dan Transformasi Pesantren" karya Said Aqil Siradj, dkk., Gus Dur menyatakan bahwa pondok pesantren dalam bacaan teknis yang dihuni oleh para santri. Pernyataan ini menunjukkan makna pentingnya ciriciri pondok pesantren sebagai sebuah lingkungan pendidikan yang integral. Sistem pendidikan pondok pesantren sebetulnya sama dengan sistem yang dipergunakan Akademi Militer, yakni dicirikan dengan adanya sebuah bangunan beranda yang di situ seseorang dapat mengambil pengalaman secara integral. Dibandingkan dengan lingkungan pendidikan parsial yang ditawarkan sistem pendidikan sekolah umum di Indonesia saat ini, sebagai budaya pendidikan nasional, pondik pesantren mempunyai kultur yang unik. Karena keunikannya, pondok pesantren digolongkan ke dalam subkultur tersendiri dalam masyarakat Indonesia. Lima ribu buah pondok pesantren yang tersebar di enam puluh delapan

${ }^{219}$ Ibid.

${ }^{220}$ Lihat Abdul Manab, Pendidikan Islam dalam Membangun Budaya Kosmopolitan Perspektif K.H. Abdurrahman Wahid, Op.cit. h. 22 
ISTIGHNA, Vol. 1, No 1, Januari 2018 P-ISSN 1979-2824

Homepage: http://e-journal.stit-islamic-village.ac.id/index.php/istighna

Deden Saeful Ridhwan MZ

Esensi Pendidikan Islam Dalam Perspektif KH. Abdurrahman Wahid

ribu desa merupakan bukti tersendiri untuk menyatakannya sebagai sebuah subkultur. $^{221}$

Menurut Gus Dur, ada tiga elemen yang mampu membentuk pondok pesantren sebagai sebuah subkultur:

1. Pola kepemimpinan pondok pesantren yang mandiri tidak terkooptasi dengan negara.

2. Kitab-kitab rujukan umum yang selalu digunakan dari berbagai abad dan,

3. Sistem nilai (value system) yang digunakan adalah bagian dari masyarakat luas. $^{222}$

\section{E. Tujuan Pendidikan Islam}

Adapun tujuan pendidikan Islam dalam perspektif K.H. Abdurrahman Wahid adalah sebagai berikut: ${ }^{223}$

\section{Pendidikan Islam Berbasis Neomodernisme}

Pendidikan Islam dalam perspektif Gus Dur, tidak lepas dari peran pesantren sebagai salah satu institusi pendidikan Islam yang menjadi wahana resistensi moral dan budaya atau pewaris tradisi intelektual Islam tradisional. Dalam perjalanan historisnya, pesantren muncul sejak awal abad hijriyah, hingga masa-masa paling akhir dari imperium Utsmaniyah di Turki pada awal abad ke-20. Dan sampai kini keberadaan pesantren masih sedemikian penting dalam pemberdayaan masyarakat. ${ }^{224}$

Neomodernisme merupakan bentuk hasil dari pemikiran yang sudah mapan dengan adanya proses perubahan dan perkembangan ilmu pengetahuan dewasa ini. Nurcholis Madjid menyatakan bahwa

${ }^{221}$ Said Aqil Siradj, et.al., Pondok Pesantren Modern "Wacana Pemberdayaan dan Transformasi Pesantren”, (Bandung: Pustaka Hidayah, 1999), Cet.1, h. 13. Lihat juga Martin Van Brinessen, Kitab Kuning dan Nilai-Nilai Tradisi (Bandung: Mizan, 1995), h. ii.

${ }^{222}$ Amin Haedari, Panorama Pesantren Dalam Cakrawala Modern, (Jakarta: Diva Pustaka, 2004), Cet.1, h. 1

${ }_{223}$ http://media.kompasiana.com/buku/2012/11/23/resensi-buku-gus-dur-dan-pendidikanislam-upaya-mengembalikan-esensi-pendidikan-di-era-global-505496.html, diunduh pada 15 April 2015 pukul 01.25 WIB.

${ }^{224}$ Ibid. Lihat juga, Deden Saeful Ridhwan, Madrasah di Indonesia Dinamika dan Eksistensinya dalam Jurnal Ma'arif NU (Jakarta: LP Ma'arif NU, 2017), h. 42. 
ISTIGHNA, Vol. 1, No 1, Januari 2018 P-ISSN 1979-2824

Homepage: http://e-journal.stit-islamic-village.ac.id/index.php/istighna

Deden Saeful Ridhwan MZ Esensi Pendidikan Islam Dalam Perspektif KH. Abdurrahman Wahid

pembaharuan merupakan proses perombakan pola pikir dan tata kerja lama yang tidak rasional untuk diganti dengan yang rasional. ${ }^{225}$

Pada hakikatnya pembaharuan pemikiran Islam merupakan suatu hasil sintesa antara pengetahuan Islam klasik dan Islam Modern. Gus Dur mencoba untuk melakukan pengkombinasian antara hal yang baik dari modernisme dan tradisionalisme untuk menghasilkan suatu yang baru, suatu yang dapat melampaui batas-batas tradisonalisme dan modernisme. Gagasan Gus Dur ini sangat kuat dan banyak mempengaruhi terhadap paradigma pendidikan khususnya dalam dunia pesantren. ${ }^{226}$

Maksud dari neomodernisme yang dimaksudkan oleh Gus Dur yaitu berdasarkan pemikirannya di atas bahwa hal yang harus bersifat neomodernis atau diperbaharui terutama adalah dari segi pemikiran, agar tidak jumud atau memacu hal yang bersifat permusuhan. Gus Dur atas pemikirannya tersebut mengajak untuk bersikap fleksibel dan luwes serta terbuka dalam beragama karena walau bagaimanapun agama tidak akan pernah terlepas dari keberadaan budaya yang sudah ada dan melekat di masyarakat luas.

2. Pendidikan Islam Berbasis Pembebasan

Dalam pandangan Gus Dur pembelajaran yang membebaskan dari belenggu-belenggu tradisionalis yang kemudian ingin dikonstruk ulang dengan melihat kepada pemikiran kritis yang terlahir oleh Barat modern. ${ }^{227}$

Dengan demikian akan memunculkan suatu term pembebasan dalam pendidikan Islam dalam koridor Islam harus dipahami secara komprehensif, bukan suatu pemahaman yang parsial yang malah akan menimbulkan suatu pandangan terhadap Islam yang pesimis. ${ }^{228}$

3. Pendidikan Islam Berbasis Multikulturalisme

${ }^{225}$ Lihat Abdul Manab, Pendidikan Islam dalam Membangun Budaya Kosmopolitan Perspektif K.H. Abdurrahman Wahid, Op.cit., h. 65-66

${ }^{226}$ Ibid., h. 65

${ }^{227}$ Ibid., h. 69

${ }^{228}$ Ibid. 
ISTIGHNA, Vol. 1, No 1, Januari 2018 P-ISSN 1979-2824

Homepage: http://e-journal.stit-islamic-village.ac.id/index.php/istighna

Deden Saeful Ridhwan MZ

Esensi Pendidikan Islam Dalam Perspektif KH. Abdurrahman Wahid

Menurut Azyumardi Azra mengenai pengertian multikulturalisme, bahwa multikulturalisme merupakan sebuah pandangan dunia yang pada akhirnya diimplementasikan dalam kebijakan kesediaan menerima kelompok lain secara sama sebagai kesatuan tanpa memperdulikan perbedaan budaya, bahasa, dan agama. ${ }^{229}$

Pendekatan yang dilakukan KH. Abdurrahman Wahid ini lebih mementingkan aktifitas budaya dalam konteks pengembangan lembagalembaga yang dapat mendorong transformasi sistem sosial secara evolutif dan gradual. Pendekatan seperti ini dapat mempermudah masuknya "agenda Islam" ke dalam "agenda nasional” bangsa secara inklusifistik.

\section{F. Kurikulum Pendidikan Islam}

Di samping memberi pendapat atau pandangan mengenai tujuan pendidikan Islam. KH. Abdurrahman Wahid pun berpendapat mengenai kurikulum pendidikan Islam, yakni sebagai berikut: ${ }^{230}$

1. Orientasi pendidikan harus lebih ditekankan kepada aspek afektif dan psikomotorik. Artinya, pendidikan lebih menitikberatkan pada pembentukan karakter peserta didik dan pembekalan keterampilan atau skill, agar setelah lulus mereka tidak mengalami kesulitan dalam mencari pekerjaan daripada hanya sekadar mengandalkan aspek kognitif (pengetahuan).

2. Dalam proses belajar mengajar guru harus mengembangkan pola student oriented sehingga terbentuk karakter kemandirian, tanggung jawab, kreatif dan inovatif pada diri peserta didik.

3. Guru harus benar-benar memahami makna pendidikan dalam arti sebenarnya. Tidak mereduksi sebatas pengajaran belaka. Artinya, proses pembelajaran peserta didik bertujuan untuk membentuk kepribadian dan

229 Azyumardi Azra, “Keragaman Indonesia: Pancasila dan Multikulturalisme”, makalah yang disampaikan pada Semiloka Nasional "Keragaman Suku, Agama, Ras, Gender sebagai Modal Sosial untuk Demokrasi dan Masyarakat Madani: Resiko, Tantangan dan Peluang”. Diselenggaran oleh Fakultas Psikologi UGM dengan Institute for Community Behavioral Change (ICBC) dan Konrad Adenauer Stiftung (KAS) di Yogyakarta 13 Agustus 2007.

${ }^{230} \mathrm{http}$ ://media.kompasiana.com/buku/2012/11/23/resensi-buku-gus-dur-dan-pendidikanislam-upaya-mengembalikan-esensi-pendidikan-di-era-global-505496.html, diunduh pada 15 April 2015 pukul 01.25 WIB. 
ISTIGHNA, Vol. 1, No 1, Januari 2018 P-ISSN 1979-2824

Homepage: http://e-journal.stit-islamic-village.ac.id/index.php/istighna

Deden Saeful Ridhwan MZ

Esensi Pendidikan Islam Dalam Perspektif KH. Abdurrahman Wahid

mendewasakan siswa bukan hanya sekedartransfer of knowledge tapi pembelajaran harus meliputi transfer of value and skill, serta pembentukan karakter (character building).

4. Perlunya pembinaan dan pelatihan-pelatihan tentang peningkatan motivasi belajar kepada peserta didik sehingga anak akan memiliki minat belajar yang tinggi.

5. Harus ditanamkan pola pendidikan yang berorientasi proses (process oriented), di mana proses lebih penting daripada hasil. Pendidikan harus berjalan di atas rel ilmu pengetahuan yang substantif. Oleh karena itu, budaya pada dunia pendidikan yang berorientasi hasil (formalitas), seperti mengejar gelar atau titel di kalangan praktisi pendidikan dan pendidik hendaknya ditinggalkan. Yang harus dikedepankan dalam pembelajaran kita sekarang adalah penguasaan pengetahuan, kadar intelektualitas, dan kompetensi keilmuan dan keahlian yang dimilikinya.

6. Sistem pembelajaran pada sekolah kejuruan mungkin bisa diterapkan pada sekolah-sekolah umum. Yaitu dengan menyeimbangkan antara teori dengan praktik dalam implementasinya. Sehingga peserta didik tidak mengalami titik kejenuhan berfikir, dan siap manakala dituntut mengaplikasikan pengetahuannya dalam masyarakat dan dunia kerja.

Salah satu cara paling efektif menerapkan kurikulum yang dapat menunjang proses belajar siswa menjadi manusia yang demokratis, pluralis artinya peserta didik dapat menerima dan mampu mengembangkan pluralisme dengan kesadaran diri, menurut Gus Dur, hendaknya peserta didik mampu belajar dari penerimaan secara terbuka terhadap pluralisme makanan. Siapapun yang memahami realitas keragaman masakan yang hampir dimiliki oleh setiap daerah di seluruh pelosok negeri ini, maka pemahamannya terhadap pluralisme justru akan semakin kokoh. Keragaman masakan yang kita miliki sebenarnya merupakan unsur kekuatan, bukan unsur ancaman. Makanan yang begitu banyak aneka ragamnya telah 
ISTIGHNA, Vol. 1, No 1, Januari 2018 P-ISSN 1979-2824

Homepage: http://e-journal.stit-islamic-village.ac.id/index.php/istighna

Deden Saeful Ridhwan MZ

Esensi Pendidikan Islam Dalam Perspektif KH. Abdurrahman Wahid

menjadi fakta bahwa pluralisme atau kebhinekaan merupakan rahmat Tuhan yang harus didayagunakan untuk kemajuan bangsa. ${ }^{231}$

\section{G. Metodologi atau Strategi Pendidikan Islam}

Ada pula metodologi atau strategi dalam pendidikan Islam perspekif $\mathrm{KH}$. Abdurrahman Wahid (Gus Dur) yaitu sebagai berikut: ${ }^{232}$

1. Strategi Politik

Gus Dur mengambil sikap dan langkah yang berbeda dengan mayoritas aktivis Islam karena ia memiliki dasar yang kuat. Wawasannya sangat luas karena ia memahami dengan baik teks-teks keagamaan dan khazanah intelektual Islam, baik klasik maupun kontemporer. Pemahamannya terhadap banyak khazanah intelektual Islam dan juga khazanah intelektual secara umum membuatnya menjadi pribadi yang memiliki pandangan komprehensif terhadap berbagai persoalan yang ada. Dan karena itulah, Gus Dur memandang keberagaman harus mendapat perlindungan dan tak ada yang memiliki hak untuk menindas apalagi meniadakan sesuatu karena alasan perbedaan, walaupun yang berbeda secara numerik hanya sejumlah kecil saja.

Strategi ini merupakan priorotas yang harus dilaksanakan sebelum melaksanakan strategi yang lain, sebab pendidikan Islam memerlukan suatu naungan politik eksplisit Islam yang akan memproklamirkan adanya pendidikan Islam tersebut. ${ }^{233}$

2. Strategi Kultural

Pondok pesantren sebagai lembaga kultural yang menggunakan simbol-simbol budaya jawa, sebagai agen pembaharuan yang memperkenalkan gagasan pembangunan pedesaan (rural development), sebgai pusat kegiatan belajar masyarakat (centre of community learning)

\footnotetext{
${ }^{231}$ Lihat Achmad Mustholih, Konsep Pendidikan Pluralisme Menurut Abdurrahman Wahid Perspektif Pendidikan Islam, (Semarang: IAIN Walisongo_skripsi, 2011), h. 166.

${ }^{232} \mathrm{http}$ ://media.kompasiana.com/buku/2012/11/23/resensi-buku-gus-dur-dan-pendidikanislam-upaya-mengembalikan-esensi-pendidikan-di-era-global-505496.html, diunduh pada 15 April 2018 pukul 13:25 WIB.

${ }^{233}$ Lihat Resdhia Maula Pracahya, Konsep K.H. Abdurrahman Wahid Tentang Pendidikan Islam Multikultural, (Jakarta: UIN Syarif Hidayatullah, 2013), h. 52
} 
ISTIGHNA, Vol. 1, No 1, Januari 2018 P-ISSN 1979-2824

Homepage: http://e-journal.stit-islamic-village.ac.id/index.php/istighna

Deden Saeful Ridhwan MZ

Esensi Pendidikan Islam Dalam Perspektif KH. Abdurrahman Wahid

dan juga pondok pesantren yang bersandar pada silabi yang dibawakan oleh Imam al-Suyuti lebih dari 500 tahun-nan lalu, dalam itmam al-dirayah. silabi inilah yang menjadi dasar acuan pondok pesantren tradisional selama ini, dengan pengembangan kajian Islam yang terbagi dalam 14 macam disiplin ilmu yang kita kenal sekarang ini, dari nahwu atau tata bahasa arab klasik hingga tafsir al-qur'an dan teks hadis nabi, semuanya dipelajari dalam lingkungan pondok pesantren sebagai sebuah lembaga pendidikan Islam. ${ }^{234}$

3. Strategi Sosio-Kultural

Strategi ini menekankan bahwa pendidikan Islam perlu mengembangkan nilai-nilai keislaman yang tidak harus dilembagakan. Artinya pendidikan Islam lebih bisa diterima masyarakat melalui lembagalembaga umum. Dengan demikian Gus Dur menempatkan pesantren pada sebuah tempat eksklusif dalam transformasi ajaran Islam. Pemikiranpemikiran Gus Dur masih terbuka bagi siapa saja yang ingin memperebut dan memperjuangkan budaya-budaya Islam tradisional, khususnya budaya pesantren, namun tidak menutup mata terhadap kondisi dan perkembangan zaman yang terus berevolusi. ${ }^{235}$

\section{Strategi Paedagogis}

Titik tekan terhadap keberhasilan penerapan pendidikan Islam mengarah pada pendidik (guru) yang berkompeten, profesional, berwawasan luas, serta karismatik. Karismatik menurut Gus Dur ialah nilai lebih dalam membangun spiritualitas antara pendidik dan peserta didik di samping pendidik juga memiliki wawasan luas tentang harmonisasi dan humanisasi yang tinggi dalam menciptakan pendidikan yang multikultural. Menurut Ainun Naim dan Achmad Syauqi penanaman nilai-nilai spiritual dan kultur sejak dini merupakan langkah yang paling efektif dalam membentuk karakter peserta didik di masa depan. ${ }^{236}$

Kehidupan beragama semua umat dapat dilihat dari dua aspek, yaitu aspek perorangan dan aspek kemasyarakatannya. Kedua aspek tersebut

${ }^{234}$ Ibid., h. 53

${ }^{235}$ Ibid.

${ }^{236}$ Ibid., h. 54 
ISTIGHNA, Vol. 1, No 1, Januari 2018 P-ISSN 1979-2824

Homepage: http://e-journal.stit-islamic-village.ac.id/index.php/istighna

Deden Saeful Ridhwan MZ

Esensi Pendidikan Islam Dalam Perspektif KH. Abdurrahman Wahid

berkaitan sangat erat, tetapi pada saat yang sama dapat dibedakan dengan jelas satu dari yang lainnya. ${ }^{237}$ Proses belajar mengajar di lingkungan pondok pesantren sebagai salah satu lembaga pendidikan Islam bukanlah sekedar menguasai ilmu-ilmu keagamaan semata, melainkan juga proses pembentukan pandangan hidup dan perilaku para santri itu yang nantinya setelah kembali dari pondok pesantren ke dalam kehidupan masyarakat. ${ }^{238}$

Pendidik dituntut untuk sebisa mungkin menjadi mediator (mengembalikan fungsi utama pendidik), karena yang dapat mengetahui kondisi kapan menggunakan metode pembelajaran partisipatif atau kapan murid sebagai subyek sehingga nantinya diharapkan anak didik dapat memunculkan kreatifitasnya. Karena yang dapat mengetahui kebutuhan anak didik adalah para pendidik. Sehingga nantinya dapat terjadi kondisi kelas yang sangat kondusif dan ideal sehingga diharapkan dengan penerapan seperti ini anak didik akan merasa lebih siap dalam menerima pelajaran dan memunculkan kreatifitasnya. ${ }^{239}$

Dunia pendidikan adalah dunia yang sangat kompleks, menantang, dan mulia. Kompleks, karena spektrumnya sangat luas, menantang karena menentukan masa depan bangsa, dan mulia karena memanusiakan manusia. Kompleksitas tersebut dapat teratasi jika guru yang menjadi ujung tombak pelaksanaan pendidikan bisa memahami peran dan fungsinya sebagai pendidik. $^{240}$

Dalam hal pendidikan, yang benar-benar Gus Dur rasakan adalah generasi muda memerlukan contoh yang baik, atau sosok yang dapat ditauladani dalam kehidupan. Bukan hanya didoktrinasi saja, tetapi perlu seorang figur yang dapat menjadi tauladan, tumpuan hati, dan harapan

\footnotetext{
${ }^{237}$ Abdurrahman Wahid, Muslim di Tengah Pergumulan, (Jakarta: Leppenas, 1983), Cet.2, h. $46-47$

${ }^{238}$ Abdurrahman Wahid, Gusdur Menjawab Kegelisahan Rakyat, (Jakarta: PT. Kompas Media Nusantara, 2007). Cet. ke-1. h. 134

${ }^{239}$ Lihat Nandirotul Umah, Pendidikan Islam di Indonesia Perspektif K.H. Abdurrahman Wahid, Op.cit., h. 75

${ }^{240}$ Ibid.
} 
ISTIGHNA, Vol. 1, No 1, Januari 2018 P-ISSN 1979-2824

Homepage: http://e-journal.stit-islamic-village.ac.id/index.php/istighna

Deden Saeful Ridhwan MZ

Esensi Pendidikan Islam Dalam Perspektif KH. Abdurrahman Wahid

secara nyata. Masalah generasi muda di Indonesia sekarang berarti hilangnya mereka figur yang menjadi contoh. ${ }^{241}$

Kehadiran pendidik yang berkualitas baik segi intelektual maupun spiritual sangatlah didambakan bagi lajunya pendidikan. Karena maju mundurnya pendidikan di sebuah Negara juga difaktori oleh kredibilitas seorang pendidik. ${ }^{242}$ Pendidikan kita sudah kehilangan akhlak/etika. Buktinya, banyak orang pintar tetapi mencuri harta rakyat (korupsi). ${ }^{243} \mathrm{Hal}$ tersebut merupakan cerminan dari kualitas pendidikan yang ada di Indonesia.

\section{H. Penutup}

Peta "keberagaman" pendidikan Islam seperti dimaksudkan di atas, haruslah bersifat lengkap dan tidak mengabaikan kenyataan yang ada. Lagi-lagi kita berhadapan dengan kenyataan sejarah, yang mempunyai hukum-hukumnya sendiri. Perkembangan keadaan, yang tidak memperhitungkan hal ini, mungkin hanya bersifat menina-bobokan kita belaka, dari tugas sebenarnya yang harus kita pikul dan laksanakan. Sikap untuk mengabaikan keberagaman ini, adalah sama dengan sikap burung onta yang menyembunyikan kepalanya di bawah timbunan pasir tanpa menyadari badanya masih tampak. Jika kita masih bersikap seperti itu, akibatnya akan menjadi sangat besar bagi perkembangan Islam di masa yang akan datang. Karenanya jalan terbaik adalah membiarkan keaneka-ragaman sangat tinggi dalam pendidikan Islam dan membiarkan perkembangan yang akan menentukan. Sebuah hal yang sulit dilakukan, namun gampang dirumuskan. Nyatanya memang benar demikian.

\section{DAFTAR PUSTAKA}

Arif, Mahmud, Pendidikan Islam Transformatif (Jogjakarta: LKiS, 2008)

Aziz, Aceng Abdul (ed), Performa Masa Depan Ma'arif NU (Jakarta: PP Ma'arif NU, 2009)

\footnotetext{
${ }^{241}$ Ibid.

${ }^{242}$ Ibid., h. 76

${ }^{243}$ Sulton Fatoni, The Wisdom of Gus Dur, Op.cit, h. 293
} 
ISTIGHNA, Vol. 1, No 1, Januari 2018 P-ISSN 1979-2824

Homepage: http://e-journal.stit-islamic-village.ac.id/index.php/istighna

Deden Saeful Ridhwan MZ Esensi Pendidikan Islam Dalam Perspektif KH. Abdurrahman Wahid

Azra, Azyumardi, "Keragaman Indonesia: Pancasila dan Multikulturalisme", makalah yang disampaikan pada Semiloka Nasional "Keragaman Suku, Agama, Ras, Gender sebagai Modal Sosial untuk Demokrasi dan Masyarakat Madani: Resiko, Tantangan dan Peluang”. Diselenggaran oleh Fakultas Psikologi UGM dengan Institute for Community Behavioral Change (ICBC) dan Konrad Adenauer Stiftung (KAS) di Yogyakarta 13 Agustus 2007.

Brinessen, Martin Van, Kitab Kuning dan Nilai-Nilai Tradisi (Bandung: Mizan, 1995)

Effendy, Bahtiar, Gus Dur dan Pupusnya Dwi Tunggal (Jakarta: Ushul Press, 2005)

E. Kosasih, Hak Gus Dur untuk Nyleneh, (Bandung: Pustaka Hidayah, 2000)

Fatoni, Sulton, The Wisdom of Gus Dur (Depok: Imania, 2014)

Haedari, Amin, Panorama Pesantren dalam Cakrawala Modern, (Jakarta: Diva Pustaka, 2004

-------, Khazanah Intelektual Pesantren II (Jakarta: Kementerian Agama RI, 2010) http://media.kompasiana.com/buku/2012/11/23/resensi-buku-gus-dur-danpendidikan-islam-upaya-mengembalikan-esensi-pendidikan-di-era-global505496.html, diunduh pada 15 April 2018 pukul 13:25 WIB.

Kartanegara, Mulyadhi, Reaktualisasi Tradisi Ilmiyah Islam (Jakarta: Baitul Ihsan, 2006)

Manab, Abdul, Pendidikan Islam dalam Membangun Budaya Kosmopolitan Perspektif K.H. Abdurrahman Wahid, (Surabaya: IAIN Sunan Ampel, 2012)

Mustholih, Achmad, Konsep Pendidikan Pluralisme Menurut Abdurrahman Wahid Perspektif Pendidikan Islam, (Semarang: IAIN Walisongo, 2011)

Pracahya, Resdhia Maula, Konsep K.H. Abdurrahman Wahid Tentang Pendidikan Islam Multikultural, (Jakarta: UIN Syarif Hidayatullah, 2013)

Siradj, Said Aqil, et.al., Pondok Pesantren Modern "Wacana Pemberdayaan dan Transformasi Pesantren”, (Bandung: Pustaka Hidayah, 1999) 
ISTIGHNA, Vol. 1, No 1, Januari 2018 P-ISSN 1979-2824

Homepage: http://e-journal.stit-islamic-village.ac.id/index.php/istighna

Deden Saeful Ridhwan MZ Esensi Pendidikan Islam Dalam Perspektif KH. Abdurrahman Wahid

Ridhwan, Deden Saeful, Madrasah di Indonesia Dinamika dan Eksistensinya dalam Jurnal Ma'arif NU (Jakarta: LP Ma'arif NU, 2017), h. 42.

Sonhadji, A. Munir, Pesantren as a Model of Non Formal Islamic Education (International Journal of Pesantren Studies, Volume 1, Number 1, 2007)

Qomar, Mujamil, Epistemologi Pendidikan Islam dari Metode Rasional hingga Metode Kritik (Jakarta: Erlangga, $\mathrm{tt})$

Turmudi, Endang (ed), Nahdlatul Ulama Ideoligy Politics and the Formation of Khaira Ummah (Jakarta: The Central Board of The Ma'arif Education Institution of NU, 2004)

Umah, Nandirotul, Pendidikan Islam di Indonesia Perspektif K.H. Abdurrahman Wahid, Program Studi Pendidikan Agama Islam, STAIN Salatiga, 2013.

Wahid, Abdurrahman, Pendidikan Islam Harus Beragam, Yogyakarta: Kedaulatan Rakyat, 2002. (Jogja: Kedaulatan Rakyat, Jumat 21/12/2002)

------, Muslim di Tengah Pergumulan, (Jakarta: Leppenas, 1983)

------, Gusdur Menjawab Kegelisahan Rakyat, (Jakarta: PT. Kompas Media Nusantara, 2007)

Yusuf, Chairul Fuad (ed), Karakteristik Majlis Taklim (Jakarta: GP Press, 2007) 